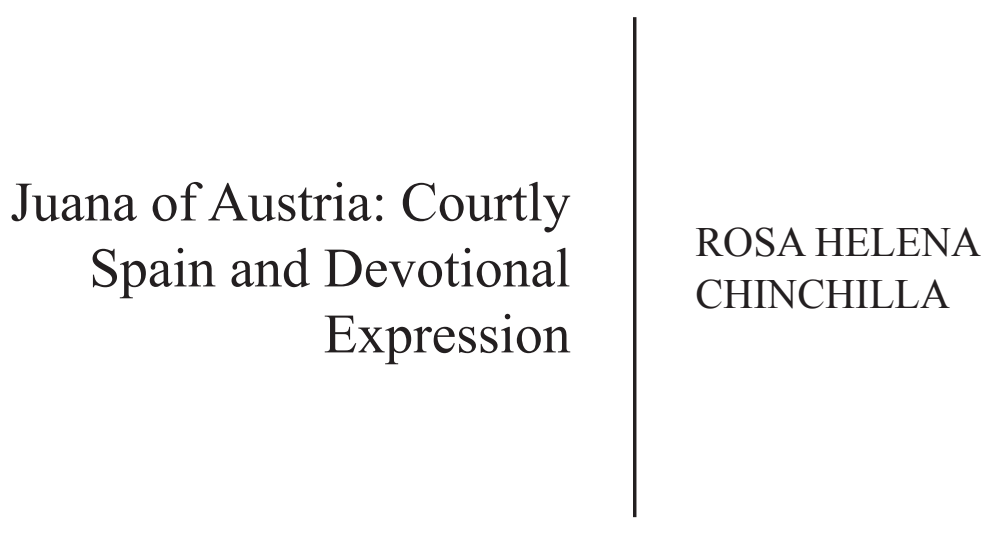

Dans la péninsule ibérique, le rôle de mécène culturel joué par l'infante Juana d'Autriche se signale par l'esprit de liberté et de tolérance qu'elle sut imposer pour mettre un terme aux persécutions dont souffraient certains écrivains tels François Borgia et Jorge de Montemayor. Par cette protection, elle influença l'esthétique de cour en l'orientant vers une plus forte et nouvelle dévotion.

s regent of Spain from 1554 to 1559 , when her brother Phillip left to
seek the thrones of England or Flanders, the Infanta Juana of Austria
l535-1575) zealously encouraged her courtiers to infuse religion into court-
ly life. ${ }^{1}$ Youngest daughter of Charles V and Isabel of Portugal, Juana wed
Prince João of Portugal in 1552 , and after his death in 1554 she gave birth to
the future king of Portugal, Sebastian. In her court Juana patronized men of
letters, most prominently Fray Luis de Granada, Francis Borgia, and Jorge
de Montemayor, whose writings propagated the idea of religious reform. Al-
though at the end of Juana's regency such religious thinkers were persecuted
by the Inquisition, they impacted the literary milieu in spite of the Inquisi-
tion's prohibitions, and the ideas of their literary contributions slowly became
the norm. The ideal Juana achieved as pious and sober regent influenced the
courts of Isabel de Valois and Ana of Austria, third and fourth wives of Phil-
lip II of Spain, as well as Phillip himself and his eldest daughter the Infanta
Clara Eugenia, later regent of Flanders. Juana's court played a pivotal role in
determining the literary tastes of the second half of the sixteenth century, and
the devotional courtly ideals made famous by her brother Phillip II.
Juana, most commonly known as Princess of Portugal or simply La
Princesa, was in the center of the hereditary maelstrom over who should gov-
ern Portugal and Spain. When João III of Portugal died in 1557, Charles V
helped his own sister Catalina to become regent of Portugal, and thereby Renaissance and Reformation / Renaissance et Réforme, XXVIII, 1 (2004) /21 
squelched Juana's claim as mother of the legitimate heir. ${ }^{2}$ Juana's brief regency ended abruptly with Phillip's final decision in 1559, after courting the crowns of England and Flanders, to return to Spain. Juana maneuvered until her death to retain her pious status of widowhood, despite repeated rumors of marriage alliances in the 1560s. Phillip kept Juana at his side as an ally in political concerns, and he entrusted her to oversee the education of his adolescent wives and young children.

The two most important religious men in Juana's court, beginning in 1552, were Francis Borgia (later Saint Francis Borgia) and Fray Luis de Granada, who taught the young princess that her principal earthly duty was to seek her own salvation and that of her subjects. Through the religious teachings of these men she helped her subjects follow a path of redemption, and in their estimate this was her greatest power. Personally, she strived for an example of queenly austerity and devotion, as noted by all her biographers. Her dress after 1554 was always black, at first an outward sign of mourning, but later a trademark of her pictorial depiction by all the court painters, as is evident in the portraits by Sánchez Coello, Sebastián de Moro, and Sofonisba de Anguissola. ${ }^{3}$ Descriptions of contemporary eye witnesses, like Catherine de Medici's French ambassadors and Phillip's court historians, in such public events as the crowning of the Infante Carlos, all emphasize her dress and manner as austere in its colour. ${ }^{4}$

Juana's direct influence on the creative process of these writers is difficult to document, except through her authorization in the publication of their books. Although royal privilege may seem a routine matter under normal circumstances, the dynamics of publishing in the 1550s warrants particular attention. Ministers who represented Prince Phillip (the future Phillip II), Queen Juana I, the Emperor Charles V, and the Princess Juana were all possible sources of royal authorization. Books of chivalry tended to be authorized by Charles V, such as Garrido de Villena's El verdadero suceso de la famosa batalla de Roncesvalles (Valencia: Mey Flandro, 1555). Compilations of law and Castilian histories were authorized by Queen Juana I, such as Leyes de Toro (Medina del Campo, 1555). An assortment of different genres have permission signed "El Príncipe" (Phillip was the legal heir to Castile after Charles V officially abdicated in 1555 after Juana I's death) even as late as 1558, such as Capitulos y leyes (Valladolid: Martínez). Yet another group bears the permission of "La Princesa," including publications originating in Valladolid, Lisbon, and Valencia. Among these are the publications by Fray Luis de Granada, Francis Borgia, and Jorge de Montemayor. ${ }^{5}$

In 1551 Fray Luis de Granada, a Dominican reformist who shared many of the Jesuit order's pious ideals, came to Evora, Portugal, where the royal 
court resided. He gave religious instruction to the royal family that included Juana of Austria, as well as Queen Catalina, Charles V's youngest sister, and her daughter, the Infanta Isabel. Borgia (after the summer of 1553) and Fray Luis served the royalty as confessors and religious guides. Consequently the Portuguese royal family was the first to patronize and personally espouse the ideals of Catholic reform in the middle of the sixteenth century. The most important texts to the new religiosity were guides for a path of salvation accessible in vulgar language. Especially important were the spiritual contemplation of Christ's life, meditation through constant prayer, frequent confession and communion. The meditative stance of such religious practices helped to name this religious reform the "recogidos" (i.e. the withdrawn).

Fray Luis de Granada published in Portugal his Castilian Guide to the Sinner (Lisbon: Juan Blavio de Colonia, 1556), dedicated to Juana's motherin-law Queen Catalina of Portugal and bearing the royal privilege of the Princess Juana. ${ }^{6}$ Such a letter is noteworthy because no other publication by Fray Luis carries this permission by the Spanish Regent, and the letter thus testifies both to the patronage relationship between them, and to the book's intended Castilian circulation. The first part guides the reader through forms of meditation and prayer, while the second reflects on Christ and presents essentially a vita Christi, considered by A. Huerga to be one of the most important and original contributions by Granada. ${ }^{7}$ The third part is a confessionary guide. Earlier, Granada had published Libro de la oración y la meditación (Salamanca: Andrea de Portonaris, 1554). Juana admired Fray Luis de Granada in Evora where she first knew him in the Portuguese Court and invited him to Spain while she was regent, although he only came to Valladolid in 1559 to defend his writings before the Inquisition. ${ }^{8}$ In the correspondence of that year Juana is named as one of the few people willing to speak on his behalf. ${ }^{9}$

During her two years residence in Portugal, Juana depended on her principal religious advisor, Francis Borgia, a Jesuit, who became the most important influence on the young princess. M. Bataillon's description of the religious atmosphere in the Princess' Portuguese court reveals that Juana requested twice daily visits from Borgia for religious guidance. ${ }^{10}$ This severe daily regiment suggests an extreme devotional attitude of prayer common to a movement associated with the recogidos. Borgia also devised moral games to teach and entertain Juana's courtiers, for example card games depicting virtues and vices.

Borgia, a cousin to Charles V and confessor to Juana's mother Isabel until her death in 1539, had known Juana since childhood. In the intervening years Borgia had met Ignatius of Loyola and had become a member of the Jesuit order. He established an important group of fifteen new Jesuit colleges 
in Portugal and Spain between 1551 and 1559, undoubtedly aided by the monarchs and regents of these kingdoms. ${ }^{11}$

Francis Borgia followed Juana back to Spain when she accepted the Regency. In his correspondence with Ignatius of Loyola and other Jesuits he argues succinctly that alliance with the Spanish monarchs serves the interests of the Jesuits. He hopes that the aid of either Juana or Phillip will secure the fortunes of the Jesuits in Spain. ${ }^{12}$ Borgia was aware that the Order and the new Catholic reforms had many enemies in Spain, but he valued dissemination of doctrine in a form that was accessible to non-Latin readers, principally the female nobility. Borgia's help was invaluable to Juana in times of personal and political crisis, as their correspondence attests. After the establishment of Juana's Castilian courts in Toros and Valladolid, Francis Borgia acts to inform Charles V regarding Queen Juana I's failing health and news of her eventual death. ${ }^{13}$ At her grandmother's death in 1556 and her father's in 1558 , Juana turned to Borgia for personal consolation and advice. ${ }^{14}$

Borgia authored Las obras muy deustas y prouechosas para qualquier fiel Christiano (Antwerp: Martin Nuncio, 1556), an eclectic collection of prayers and a religious guide. Although Borgia disclaimed authorship in post-1559 correspondence, it is still thought to be a compilation by one of his followers and a reflection of his teachings. In this small guide to the faithful, the methods used by Borgia to teach religious practice share a similar methodology to Fray Luis de Granada's ideas on meditation on concrete events in Christ's life. In 1558 this book was included in the Inquisitorial Index published in 1559. Borgia left Castile never to return after the infamous auto-da$f e ́$ of 1558 , in which he was forced to witness one of his cousins undergo public trial and humiliation. He could depend on Juana's help only until Phillip's return. Juana herself could have been implicated in these proceedings if she dared to defend those religious men whom she most admired. The Catholic Church in Spain throughout the 1560s refused to authorize his books in either Latin or Castilian. ${ }^{15}$

Borgia had clearly anticipated the importance of the Regent Juana's influence in creating new havens for the type of Catholicism espoused by the Jesuits, but he failed to anticipate the powerlessness of the monarch before a Grand Inquisitor like Valdés. The secrecy of Juana's vows to the Jesuit order, under the pseudonym Mateo Sánchez, which Borgia, Loyola, and Laínez used to refer to the Princess, suggests that the Jesuit reform as envisioned by these men was still perceived to be perilously close to Protestant reform, undoubtedly because these religious thinkers made accessible religious texts in the vernacular, and the resemblance to Lutheranism on this tenet was overwhelming for church authorities. ${ }^{16}$ In fact the 1558 auto-da-fé's purpose was 
described in precisely those terms by Charles V and Phillip II: the destruction of a new Lutheranism in Spain. ${ }^{17}$ The importance of Juana's desire to become an active member of the Jesuit order underscores her vulnerability to Charles's decree against all followers of the new piety, regardless of their position in government.

As her governing duties waned, Juana set herself the task of founding the Convent of the Descalzas Reales, following Borgia's example as founder of colleges. In 1557 she first envisioned the convent in Valladolid, but in 1559 she decided to transfer the convent to Madrid. Juana founded a religious haven for courtly women to profess in a Franciscan convent modeled after one Borgia himself had founded in Valencia. Only two precedents existed in Spain for establishing royal monasteries: Santa María la Real de las Huelgas in Burgos, founded by Alfonso VIII and Eleanor of England in 1186 and destined to be a royal pantheon for Castilian Kings, and Santa María la Real de Tordesillas (or Santa Clara de Tordesillas) founded in the 1390s as a pantheon for Pedro I and Blanca of Bourbon and their immediate family. Queen Juana I was imprisoned in the Tordesilla's monastery from 1509 until her death in 1556. Significantly, the Convent of the Descalzas Reales included both purposes, being first a resting place for the Princess Juana, and second a haven for noblewomen. ${ }^{18}$

This royal monastery was the model for the Convent of the Encarnación, founded by Queen Margarita in 1613, and the Convent of Santa Isabel, relocated to Madrid by Queen Margarita in 1615. The concept is closely allied to Phillip II's formulation of the Monastery of El Escorial founded in 1570: pantheon for Spanish royalty, royal monastery, and palace. Juana's monastic foundation is her most lasting legacy to the Spanish Hapsburgs. The monarchs who followed all adopted outward signs of their devotion, and at the same time created personal refuges for their private meditation, or retired to monasteries already in existence. ${ }^{19}$ Juana combined her religious zeal with royal authority in an exemplary fashion, and furthermore enjoyed the devotion of the monastic life without professing vows publicly.

The work of Jorge de Montemayor, poet and court musician, is a prime example of the way Juana's religious life affected the literary contributions of her courtiers. Montemayor entered Juana's service in 1548, followed her to Portugal, and returned to the court in Valladolid after 1554. In an eclectic anthology of his poetry published in 1553 and reprinted in the well-known edition of 1554, and in many sixteenth-century editions thereafter, Montemayor highlighted the importance of his patrons, both João and Juana, and their preference for devotional poetry. ${ }^{20}$ In the 1554 edition, religious poetrystanding alone and separate from the courtly and burlesque poetry - is set off 
by a second dedication to the Prince and Princess. In 1558 Montemayor published a Segundo Cancionero (Antwerp: Ian Lalio, 1558) containing poetry based on psalms and events of the life of Christ. This second devotional collection has Juana's permission, although the book is not dedicated to her. ${ }^{21}$ Also the poem entitled "Regimiento de príncipes" is a Christian manual for the ruler, dedicated to Sebastian, Juana's son and now heir to the Portuguese throne. ${ }^{22}$ In Spain no other poet in the sixteenth century enjoyed this degree of royal patronage.

Montemayor's second poetic output was Ausias March's anthology in Catalan (Valladolid, 1555), and a Castilian translation of the same (Valencia, 1561). The 1555 edition also bears the permission of Juana de Austria. ${ }^{23}$ Ausias March resided in the Kingdom of Valencia, specifically in Gandia, home to the Borgia family. In fact, the last poem of the 1561 collection is a reply to March's sonnet by Ucleta [sic Tecla] Borgia, identified in the text as grandmother of Francis Borgia. ${ }^{24}$ The biographical connection to the major religious figure from Valencia in Juana's court suggests further affinities between Borgia's religious thought and March's philosophical sonnets and songs. March's philosophical love poetry has a consolatory nature greatly admired by Montemayor as is evident in his meditative religious poetry. March represented an alternate type to the Petrarchan lyric found in the most popular poet, Garcilaso de la Vega. ${ }^{25}$

Montemayor's pastoral novel, Diana, was his last important project from the $1550 \mathrm{~s}$, although it has not been ascertained if the novel was composed early in the decade, and published later, or composed close to $1558 .^{26}$ The text makes reference to Juana as the "Cesarean Princess" in Valladolid, which suggests that the text was composed after 1554. Included in Part IV among the gallery of noblewomen are Juana and the Portuguese princesses, as well as Borgia's cousins. The first edition is dedicated to the Count of Castellá, Bicorp, and Sessa, important towns in Valencia. Although Juana's personal itinerary is not documented, she did travel to Aragon and Valencia between 1557 and 1558 .

The connections between the pastoral novel in a fictitious courtly world and the spiritual life of Juana's court do not seem at first obvious. Many critics have suggested that Diana's pastoral message is constantly entwined with a Catholic allegory of virtues. Chevalier suggested that Diana should be read as a "roman à clef" for Juana's courtly world. ${ }^{27}$ More significantly Juan Montero suggests that the fountain theme of Book I, wherein a mirror reflects the beloved, and in Book IV, where the mirror represents a source of memory, are both motifs used by later mystic poets such as St. John of the Cross. ${ }^{28}$ Bataillon and Creel after him have shown conclusively that Savanarola's 
writings were read by Montemayor and other religious writers at that time. ${ }^{29}$ Although no one has undertaken a religious interpretation of Diana, many critics have suggested a moral quality and spirituality to the novel. ${ }^{30}$ The broader heroics of a chaste woman whose interior life is very complex do represent a principal ideal of Juana and the religious men of letters who wrote at her court.

Other important religious books that were dedicated to Juana the regent include three religious treatises: Fray Alonso de Orozco's Recopilacion (1555), Fray Alonso Muñoz's Homélies de Savaranole (1556), and Fray Diego de Estella's Libro de la vanidad del mundo (1562). ${ }^{31}$ Other religious books such as Bernardo de Nieva's Sumario manual de la christiana consciencia (Medina del Campo, 1556) bear the Princess' authorization, although they are not dedicated to her. Another important secular poem with philosophical overtones dedicated to Juana is Hermosura Psiche by Juan de Malara, the renowned Sevillian classicist. In his dedicatory preface to Juana, he emphasizes that the beauty of Psyche is like the human soul. ${ }^{32}$

In 1558 the accusations of the heresy of Lutheranism directed toward Bartolomé de Carranza, Bishop of Seville, by the Grand Inquisitor Fernando de Valdés, destabilized the reforms initiated by Fray Luis de Granada, Francis Borgia, Juan de Avila, and Carranza. Many noble men and women were implicated in this first assault on the recogidos. Spiritual literature in the vernacular was especially suspect. The autos- $d a-f e ́$, notoriously celebrated in Valladolid, represented an ominous threat to the religious thinkers that Juana had fostered and invited to Spain. Juana's attendance was mandatory at both these macabre scenarios, and although her presence is used as evidence of her support of the Inquisition's ideas, it was unthinkable not to attend. At this time Phillip II's return was imminent and her weakened position was evident. She did act to prevent proceedings against many religious people whom she had patronized. The ominous Inquisitorial Index banned all vernacular use of the Bible. Many convents throughout Spain were confused as to whether all devotional books were banned. ${ }^{33}$ Carranza was imprisoned and died in the 1570s. Borgia and Luis de Granada fled and never returned to Spain. Fr. Luis de Granada continued to enjoy royal favour in Portugal by Catherine, now Regent of her grandson Sebastian, and Borgia eventually went to Rome. Montemayor also left Castille, possibly residing first in Valencia and then leaving for Italy where he died in a duel in 1561 . He may have fled Spain in fear of religious persecution.

Upon Phillip's arrival in September 1559, Juana returned to the status of Infanta. Now completely bound by the rigid rules of Hapsburg royalty, Juana was still able to enjoy a degree of personal and monetary independ- 
ence, to promote her ideals through her manner, bearing and status as the founder of her convent, which she continued to manage.

Juana's primary role in the court of Phillip II was to educate the young Queen Isabel de Valois in the ways of the Spanish Hapsburgs, and after 1566 to help with the care of the Infantas Clara Eugenia and Catalina Micaela. Juana always accompanied the young queen to the palace in Aranjuez, as documented by the French ambassadors and court chroniclers. One incident of note was preserved in a document that narrates the events of the 1565 Epiphany. The entertainment consisted in guessing the names of plays performed by Juana and Isabel and sixteen ladies at court. The six scenes depicted by Juana are derived from Montemayor's Diana and his poems. ${ }^{34}$ Juana's continued reliance on allegorical games, using these passages from Diana about Christianity, chastity, and worldly illusions, shows her affinity for a methodology like Borja's playing cards. She presents religious teaching subtly, not overtly, by using the novel as a means of teaching those under her care.

Juana maintained an important influence in the court by holding steadfastly to her religious ideals in her personal conduct and demeanor. Despite many possible alliances, Juana never remarried. She seemed to some a beautiful, austere widow, dressed perpetually in mourning. To others she seemed devoted in the extreme to her monastic world, even to the point of having private quarters in her convent. Juana kept this strict code in her life undoubtedly because of her vows to the Jesuit order. Her conduct had to be at all times in keeping with her station. She followed strictly the guidelines set forth by Loyola and Borgia years earlier. The single extant portrait of Juana from the period following her regency by Sofonisba de Anguissola (1570) represents Juana with a young child at her side, who holds three roses, ostensibly signifying the vows of chastity, poverty, and obedience. One of Juana's hands is gloved, while the other is wrapped around the child's hand, with the child representing a young noblewoman entering the convent. ${ }^{35}$ The painting could also allude to the gardener role that Juana has made for herself, a spiritual garden filled with young women. The Descalzas Reales contains the personal portraits of Juana's son Sebastian, a portrait of Francis Borgia, and various copies of Juana's portrait by Sánchez Coello, who was part of Juana's courtly retinue in Portugal and Valladolid, and who was employed after 1559 by Phillip as court painter. ${ }^{36}$

After Isabel's death in 1568, Ana of Austria wed Phillip II. She also came under Juana's tutelage and admired the strength of the Princess. Queen Anne's fervent religiosity was inspired by Juana. At Juana's death in 1573, Phillip personally saw to the administration of her royal convent. Juana's 
patronage of religious men, writers, and artists, despite the oppressive tone set by the Inquisition, suggests that Phillip II's court adopted similar artistic projects, although inspired by a very different set of political, as well as personal, circumstances. Her niece Clara Eugenia also became a patroness of religious poets and may also have been influenced by her aunt to adopt an ascetic way of life after her own widowhood, as is attested especially in the famous portrait by Van Dyke of her in a Franciscan tertiary habit. ${ }^{37}$

Although the courtly world of Juana has not been fully documented, we note its importance as a haven for artistic manifestations of devotional literature. She patronized Montemayor, Borgia, and Fray Luis de Granada in the $1550 \mathrm{~s}$; by her determination to keep her religious ideals known in court circles, she fostered links between these early influential writers and the popular religious writers after 1570. Her influence on later Hapsburg manifestations of religiosity is compelling.

\section{University of Connecticut}

\section{Notes}

1. The most notable biographies of Juana are M. Bataillon, "Jeanne d'Autriche, Princesse de Portugal," Etudes sur le Portugal au temps de l'humanisme (Coimbra: Universidade de Coimbra, 1952), pp. 257-83; M. J. Rodríguez Salgado, The Changing Face of Empire. Charles V, Phillip II and Hapsburg Authority 1551-1559 (Cambridge: Cambridge University Press, 1988); Carlos Javier de Carlos Morales, "Grupos de poder en el consejo de Hacienda de Castilla: 1551-1556," Instituciones y élites de poder en la monarquía hispana durante el siglo XVI (Madrid: Ediciones de la Universidad Autónoma de Madrid, 1992), pp. 107-37. The last two place Juana's regency government as dictating much of the policy in opposition to Charles V and Phillip II. See Luis Fernández de Retana, Juana de Austria (Madrid: El Perpetuo Socorro, 1955): a biography with incomplete documentation, which emphasizes the subservient roles Juana has in Phillip's reign and which portrays events in a romantic light. The most recent historical biography is by Antonio Villacorta Baños, La Jesuita: Juana de Austria (Barcelona: Editorial Ariel, 2005).

2. Corpus documental de Carlos V, ed. Manuel Fernández Alvárez (Salamanca: Universidad de Salamanca, 1979), vol. 4, pp. 331-3. Charles V writes to Fadrique Enríquez with his orders: "Y en esta plática no hauéis de hazer mención ninguna de la Princesa, mi hija, ni tampoco quando le habláredes de su parte, no embargante lo que os ordena por su instrucción" (p. 332). [And in this conversation you shall not mention the Princess, my daughter, neither when you give news of her, notwithstanding what she has ordered through her instructions.] Charles then writes to Juana that it is not convenient at this time that she should negotiate with his sister, Catalina, and emphasizes "Y más vos, siendo hija” (p.333). [And especially you, being only a daughter.] Alvárez's comment in the footnote spells out that despite his retirement in Yuste, Charles V continues to behave as the chief of the dynasty whose orders must be obeyed.

3. Juana's portraits date to her regency and were all painted by Sánchez Coello and Antonio Moro, except two: one by Anguissola (1570, Isabella Stewart Gardner Museum), and the 
other in the Pardo Palace (today in Brussels) painted in 1552. All of the later paintings show Juana in a regal sovereign pose. She wears a black dress, signifying her seriousness and her abstention from worldly life. Antonio Moro's portrait of Juana included in the royal gallery in the Pardo Palace is significant in its placement, next to her parents and brother Phillip at the head, and in its iconography because the young black child is symbolic of her marriage to the Prince of Portugal. This image is the one Phillip II wanted to project of his sister in the 1570s, as the link to the acquisition of the Portuguese Empire: see María Kusche, "La antigua galería de retratos del Pardo," Archivo Español de Arte 72 (1992), no. 286, pp. 1-27.

4. Luis Cabrera de Córdoba, Historia de Felipe II, Rey de España, ed. José Martínez Millán and Carlos Javier de Carlos Morales (Salamanca: Junta de Castilla y León, 1998), p. 212. Here the Princess is described as "vestida de negro con alguna guarnición, piedras y perlas en el tocado y manos" [dressed in black, with some adornments, precious stones and pearls in her headdress and hands] at the coronation of the Infante Carlos. In Relaciones históricas de los siglos XVI y XVII (Madrid: Sociedad de Bibliófilos Españoles, 1876), p. 59, the Princess is described as wearing black with pearl adornments for the wedding of Isabel and Phillip.

5. It is noteworthy that the publishing industry in the 1550 s was in a decline and that the great majority of books were published outside of Spain, particularly in Antwerp. See Theodore Beardsley, "Spanish Printers and the Classics: 1482-1599," Hispanic Review 47 (1979), pp. 24-35. Beardsley writes, "In the 1540s a major revolution occurs in Spanish publishing; the majority of Spanish books are published outside of Spain, primarily in Antwerp, but also in Lyons, Toulouse, Paris, Louvain, Strasbourg, Cologne, Venice, Lisbon, and Coimbra" (p. 30).

6. Fray Luis de Granada, Obras Completas: Guía de Pecadores (texto primitivo) (Madrid: Fundación Universitaria Española Dominicos de Andalucía, 1994), vol. 2, including the original text that concludes: "Fecha en Valladolid, a treinta días del mes de Marzo de mil y quinientos y cincuenta y siete años. La Princesa [Written in Valladolid, on the thirtieth day of March of fifteen hundred and fifty seven years. The Princess], pp. 210-11.

7. Alvaro Huerga, "Nota Crítica," in Fray Luis de Granada, vol. 2, p. 442.

8. For Fray Luis de Granada's itinerary in 1559, see José María Balcells, "Introducción," in Fray Luis de Granada, Introducción del símbolo de la Fe (Madrid: Cátedra, 1989), p. 24.

9. Fray Luis de Granada, Obras Completas: Epistolario (Madrid: Fundación Universitaria Española Dominicos de Andalucía, 1998), vol. 19, p. 36, “Ayúdanme a esto el padre Francisco, el embaxador de Portugal, Gutierre López y don García y la Princesa. Y con todo esto habrá un pedazo de trabajo, por estar el arzobispo tan contrario a cosas (como él llama) de contemplación para mujeres de carpinteros, etc." [Father Francis helps me in this, the ambassador of Portugal Gutierre López and Don García, and the Princess. And with all of this there will be some work, because the archbishop is so contrary to contemplative things (as he called them) for wives of carpenters, etc.]

10. Bataillon, pp. 264-5.

11. Melquíades Andrés, La teología española en el siglo XVI (Madrid: Biblioteca de Autores Cristianos, 1976), pp. 178-9. 
12. Sanctus Franciscus Borgia, Letter to Joannes de Castro, 28 October 1555: "no sé si abastará matar tanto fuego, si no se ponen personas de mucha authoridad y poder, como es el príncipe y la princesa; pues S.A, agora rige estos reynos de España, ella sería parte para remediarlo" [I don't know if that will be enough to squelch this fire, if we do not also bring into our fold persons of great power as are the prince and the princess; well Her Highness rules these Kingdoms of Spain, she could resolve these problems], vol. 3, p. 250, from Sanctus Franciscus Borgia, quartus gandiae dux et societatis jesu praepositus generalis tertius (1539-1565), Monumenta Historica Societatis Jesu (Madrid: Lopez del Horno, 1908).

13. Borgia writes to J. Lainez in Rome: "Matheo Sánchez esta como suele, y antes con mayor augmento en la deuoción de la Compañía y en su aprouechamiento. Hanle llevado mucho tantas muertes, y con razón, sino que lo lleua con grand prudencia y xpinadad" [Matheo Sanchez (pseudonym for Juana) is as [she] always is, and even with greater devotion to the Company and in her improvement. She grieves the many deaths that have touched her, and with good reason, she takes everything with great prudence and Christianity.] Borgia, vol. 3, p. 418.

14. Corpus documental de Carlos V, vol. 4, pp. 214, 218-20.

15. See correspondence with Pedro Laín, in Borgia, vol. 3, after 1561, and also Cándido de Dalmases, "San Francisco de Borja y la Inquisición española 1559-1561," in Archivum Historicum Societatis Iesu 41 (1972), pp. 111, 121 and 125-6. The Inquisition did not approve Borgia's publications after 1559 in Latin or Castilian during his lifetime.

16. For the identification of Juana de Austria with Mateo Sánchez, see Cándido de Dalmases, pp. 48-135: she is referred to as The Princess, Mateo Sánchez, and Montoya (p. 50). See also Borgia, vol. 3, p. 301; and Hugo Rahner, Saint Ignatius Loyola, Letters to Women (Edinburgh and London: Nelson, 1960), pp. 52-74.

17. See Corpus Documental de Carlos V, p. 424, Letter dated 3 May 1558, in which Charles $\mathrm{V}$, after insisting on the harshest punishment for the accused heretics, adds: "Y esto sin excepción de persona alguna" [and this without exception to any person].

18. Leticia Sánchez Hernández, Patronato regio y órdenes religiosas femeninas en el Madrid de los Austrias: Descalzas Reales, Encarnación y Santa Isabel (Madrid: Fundación Universitaria Española, 1997), p. 59.

19. See Hernández: "Las fundaciones encarnan la expresión palpable de la relación que el hombre mantiene con Dios, y representan una manera de encausar y justificar la riqueza acumulada en vida, es decir, un procedimiento por el que los fundadoresen - este caso la familia real-pueden presentar una obra buena ante Dios cuando les llegue la hora de la muerte. En los testamentos de la princesa Juana de Portugal y de la emperatriz María de Austria, así como en las intenciones que animarán a Margarita de Austria para fundar la Encarnación y trasladar Santa Isabel, quedan plenamente manifestados los fines en los que debe emplearse la mencionada riqueza" [The foundations bring to life the palpable expression of the relationship that man has with God, and they represent a way to defend and justify the riches accumulated in life, in other words, a way in which the founders - in this case the royal family — can present a work before God at the hour of death. In the wills of the Princess Juana of Portugal, and of the Empress Maria of Austria, as well as the intent of Margarita de Austria in her foundation of Encarnacion and the transfer of 
Santa Isabel, the ends in which said wealth should be employed are fully manifested], pp. 32-33.

20. Only one edition is extant at the Hispanic Society of America with the date ca. 1553. Juan Montero, "Prólogo," La Diana (Barcelona: Ediciones Crítica, 1996), p. xxix, believes it is dated earlier in 1552.

21. "El privilegio" reads "Concede su Magestad a Iorge de Monte Mayor criado de la Serenissima Princesa de Portugal su hermana que por tiempo de quatro años nadie pueda vender ni emprimir este libro sin su licencia sola pena en el original privilegio contenida" [His majesty concedes Jorge de Montemayor servant of the Most Serene Princess of Portugal, his sister, that for four years no one shall sell or print this book without licence under the penalty of the original privilege therein contained] (f. A2). The dedication is for Jerónimo de Salamanca, and in the prologue he states that the book has the approval of theologians from the Colegio de San Gregorio de Valladolid, the same college where Fr. Luis de Granada was ordained and later shielded him from the Inquisitor Valdés.

22. Jorge de Montemayor, Cancionero espiritual (Antwerp: Nuncio, 1558), folio 30.

23. Marcelino Menéndez y Pelayo, Orígenes de la Novela (Santander: Aldus, 1940), p. 259, adds that Montemayor had to look at five different manuscripts that were only available in Valencia.

24. Jorge de Montemayor, Poesía completa (Madrid: Turner, 1996), p. 727.

25. The generally held notion of a poetic revolution in Spain with the publication of Sebastián de Córdoba's Garcilaso a lo divino in 1571 (reprinted in Madrid: Castalia, 1971) ignores the important cluster of religious and philosophical poetry diffused between 1554 and 1561. Taken together, Montemayor's anthologies and his translation of March's poetry form a corpus of spiritual contemplative religious poetry. Readers like Juana herself who sought contemplative entertainment had an accessible form of vernacular literature that responded to their spiritual needs.

26. See Julian Arribas, "Introducción," Los siete libros de la Diana (Woodbridge, UK; Rochester, NY: Tamesis, 1996), p. 118, where Arribas states that the composition date is certainly earlier than 1559 , but not earlier than 1555 .

27. Maxime Chevalier, "La Diana de Montemayor y su público en la España del s. XVI," Creación y público en la literatura española (Madrid: Castalia, 1974), pp. 40-55.

28. Juan Montero, "De la Diana de Montemayor al Cantico espiritual: Especulaciones en la fuente," Edad de Oro XI (1992), p. 116.

29. See Bataillon, "Une source de Gil Vicente et Montemor," Études sur le Portugal au temps de l'humanisme (Coimbra: Universidade de Coimbra, 1952), pp. 197-218; and Bryant Creel, The Religious Poetry of Jorge de Montemayor (London: Tamesis, 1981), pp. 90-91.

30. See Elizabeth Rhodes, The Unrecognized Precursors of Montemayor's Diana (Columbia, MO: University of Missouri Press, 1992).

31. These books in particular are noted by Bataillon, p. 270.

32. This important secular manuscript is reproduced only in part in Marcelino Menéndez Pelayo, Bibliografía hispano-latina clásica (Santander: Aldus, 1940), pp. 101-26.

33. Melquíades Andrés, La teoloía española en el siglo XVI (Madrid: Biblioteca de Autores Cristianos, 1977), p. 625. 
34. Agustín de Amezúa, Isabel de Valois (Madrid: Gráficas Ultra, 1949), vol. 3, pp. 468-72, reproduces the court document in its entirety describing the eleven separate scenes, five staged by Isabel and six staged by Juana.

35. María Ferino Pagden and Maria Kusche, Sofonisba de Anguissola, A Renaissance Woman (Washington, DC: The National Museum of Women in the Arts, 1995), p. 66.

36. Stephanie Breuer, Alonso Sánchez Coello (Munich: Ludwig-Maximilians Universität $\mathrm{PhD}$ dissertation, 1984), p. 26. She also documents the three remaining portraits of Juana, pp. 200-203.

37. See Ana Navarro, Antología poética de escritoras de los siglos XVI y XVII (Madrid: Castalia, 1989), p. 79; Navarro describes the poet Isabel de Castro y Andrade as belonging to the literary Academy of the Infanta Clara Eugenia in Madrid between 1592-1595. 